\title{
Veranderinge in aandelekapitaal
}

\author{
F.J. Mostert \\ Departement Bedryfsekonomie, Universiteit van Stellenbosch
}

\begin{abstract}
Changes In share capital. A company's ordinary share capital can be altered by changing the amount of issued share capital or the number of issued shares or a combination of the two. Such changes can be effected through rights issues, capitalization issues, the subdivision of shares, the reduction of share capital and the consolidation of shares. Each of these avenues is dealt with in this article, which embodies selected results of an empirical survey of companies listed on the Johannesburg Stock Exchange. The discussion of rights issues includes the reasons for such issues, the discounts allowed on prevailing market prices, the factors which influence the success of an issue, and the effects of rights issues on the market prices of existing shares and letters of allotment. The reasons for and benefits of sub-divisions of shares and capitalization issues are considered, as are the reasons for and financial implications of a reduction in a company's issued share capital.
\end{abstract}

S. Afr. J. Bus. Mgmt. 1981, 12: 1-4

'n Maatskappy se gewone aandelekapitaal kan gewysig word deur die bedrag van uitgereikte aandelekapitaal of die aantal uitgereikte aandele te verander of ' $n$ kombinasie van die twee. Sodanige veranderings kan teweeggebring word deur regteuitgiftes, kapitalisasie-uitgiftes, die onderverdeling van aandele, die vermindering van aandelekapitaal en die konsolidasie van aandele. Elk van hierdie metodes word in die ar. tikel bespreek wat geselekteerde resultate van 'n empiriese oorsig van maatskappye, wat op die Johannesburgse Effektebeurs genoteer is, bevat. Die bespreking van regteuitgiftes bevat die redes vir sodanige uitgiftes, die diskonto's wat op heersende markpryse toegelaat word, die faktore wat die sukses van 'n uitgifte beïnvloed, on die uitwerking van regte-uitgiftes op die markpryse van bestaande aandele en toekenningsbriewe. Die redes vir en voordele van die onderverdeling van aandele en kapitalisasie-uitgiftes word bespreek sowel as die redes vir en finansiele implikasies van 'n vermindering in die maatskappy se uitgereikte aandelekapitaal.

S.Afr. Tydskr. Bedryfsl. 1981, 12: 1-4
Die verkryging van 'n maatskappy se kapitaal kan hoofsaaklik uit twee bronne geskied, te wete eie kapitaalverskaffers en vreemde kapitaalverskaffers. Eie kapitaal is daardie gedeelte van die totale kapitaal wat aan die maatskappy se aandeelhouers behoort en bestaan uit gewone en voorkeuraandelekapitaal en verdeelbare en nie-verdeelbare reserwes. Die eie kapitaal kan verder in eksterne en interne kapitaal verdeel word. So is gewone en voorkeuraandelekapitaal eksterne kapitaal, terwyl verdeelbare en nie-verdeelbare reserwes, behalwe die aandelepremie wat uit eksterne bronne kom, as interne kapitaal beskou word.

Die kapitaalstruktuur van 'n maatskappy is voortdurend onderhewig aan verandering. Hierdie artikel fokus slegs op gewone aandelekapitaal.

Onder veranderinge in gewone aandelekapitaal word twee moontlikhede verstaan, naamlik:

- 'n verandering in die uitgereikte aandelekapitaal, met of sonder 'n gepaardgaande verandering in die aantal uitgereikte aandele;

- 'n verandering in die aantal uitgereikte aandele terwyl die uitgereikte aandelekapitaal konstant bly.

In hierdie artikel word vyf wyses van verandering in gewone aandelekapitaal bespreek, te wete:

- Regte-uitgiftes

- Kapitalisasie-uitgiftes (bonusuitgiftes)

- Onderverdelings van aandele

- Gelyktydige verminderinge van aandelekapitaal en konsolidasies van aandele

- Verminderinge van aandelekapitaal.

'n Vraeboog is aan al die genoteerde maatskappye gestuur wat die bogenoemde veranderinge in hulle gewone aandelekapitaal gedurende 1965 tot 1974 onderneem het.' Die aantal meewerkende maatskappye by regte-uitgiftes was 80 , by kapitalisasie-uitgiftes 61 , by onderverdelings van aandele 27 , by gelyktydige verminderinge van aandelekapitaal en konsolidasies van aandele drie (uit 'n moontlike agt), en by verminderinge van aandelekapitaal ses (uit 'n moontlike 16). Die belangrikste bevindings wat uit hierdie navorsing voortgespruit het, word vervolgens aan die orde gestel.
F.J. Mostert
Departement Bedryfsekonomie, Universiteit van Stellenbosch,
Stellenbosch 7600 


\section{Regte-ultgiftes}

Soos algemeen bekend, behels 'n regte-uitgifte die voorkeurreg wat deur 'n maatskappy aan sy bestaande aandeelhouers gegee word om by die uitgifte van addisionele aandele van dieselfde soort as die bestaande aandele hulle pro rata aandeelhouersbelang te handhaaf deur die addisionele aandele op te neem. Om 'n regte-uitgifte aantreklik te maak vir die bestaande aandeelhouers word die addisionele aandele teen 'n laer prys as die heersende markprys uitgereik. Gevolglik moet die aandeelhouers die nuwe aandele opneem om hulle proporsionele belang in die maatskappy te handhaaf.

Dit volg logies dat die addisionele aandelekapitaal 'n definitiewe aanwendingsmoontlikheid moet bevredig. So het die meeste maatskappye 'n kapitaalbehoefte ondervind om hulle uitbreidings te finansier. Dit lyk asof die maatskappye vervangingsinvesterings nog kon hanteer deur interne fondse te gebruik, maar dat 'n probleem opgeduik het wanneer uitbreidingsinvesterings gemaak moes word. Vir bestaande aandeelhouers was die verwagte rentabiliteit op die addisionele aandelekapitaal 'n kritiese faktor. Dit is dan ook geensins verbasend dat $65 \%$ van die betrokke maatskappye reeds by die uitnodiging om vir addisionele aandele in te skryf die verwagte dividendkoers vermeld het nie.

Om die uitgifte aantreklik te maak, word 'n diskonto in terme van die heersende markprys toegelaat wanneer die uitgifteprys bepaal word. Die diskontokoers was by $81 \%$ van die regte-uitgiftes wat ondersoek is gelyk aan of minder as $35 \%$. Verder kon geen betekenisvolle korrelasie gevind word tussen die omvang van die diskontokoerse en stygende en dalende fases van die konjunktuur nie. Dit wil gevolglik voorkom asof die maatskappye by die bepaling van die diskontokoerse weinige waarde geheg het aan die heersende konjunktuurfase wat van toepassing was.

Die uitgifteverhouding, dit is die aantal nuwe aandele vir die aantal bestaande aandele, het 'n groot variasie getoon. Logiesgewys is dit aanvaarbaar, want die aantal nuwe aandele sal bepaal word deur die kapitaalbehoeftes en die uitgifteprys, beide faktore wat wisselend van aard is.

Die regte-uitgiftes wat in die studie ingesluit was, kan grotendeels as geslaagd beskou word omdat by $76 \%$ van die gevalle $90 \%$ of meer van die addisionele aandele wel opgeneem is. 'n Goedbeplande regte-uitgifte het skynbaar 'n goeie kans om te slaag. 'n Verdere ontleding het ook getoon dat daar geen beduidende verband bestaan tussen die omvang van die totale bates van 'n maatskappy en die persentasie van die nuwe aandele wat opgeneem word nie. Die hipotese wat gestel is, naamlik dat regteuitgiftes gedurende 'n stygende konjunktuurfase ' $n$ beter kans op sukses het as gedurende 'n dalende fase, is ook empiries bewys. ' $n$ Verdere aspek van belang by die sukses van 'n regte-uitgifte is sekerlik die omvang van die diskonto toegelaat in terme van die markprys by die bepaling van die uitgifteprys. So is bevind dat indien die diskontokoers ten minste $35 \%$ was, daar by al die betrokke maatskappye ten minste $90 \%$ van die nuwe aandele opgeneem is. Die sukses van 'n regte-uitgifte word primêr gekoppel aan die bepaling van die uitgifteprys en tweedens speel die heersende konjunktuurfase ook 'n belangrike rol. In teenstelling met die voorafgaande bevindings het die betrokke maatskappye die volgende drie faktore in ' $n$ dalende orde aangedui as bepalend vir die sukses van 'n regte-uitgifte: Eerstens word die aansien van die maatskappy as die belangrikste faktor beskou, voorts is die verskil tussen die markprys en die uitgifteprys ook bepalend vir die sukses van 'n regte-uitgifte en laastens word veel waarde geheg aan die konjunktuurfase.

Die onderskrywing van 'n regte-uitgifte is so te sê 'n standaardprosedure in Suid-Afrika. Slegs vier maatskappye het nie van onderskrywing gebruik gemaak nie. 'n Onwillekeurige vraag is of die onderskrywing van 'n regte-uitgifte werklik nodig is indien die diskonto toegelaat in terme van die markprys by die bepaling van die uitgifteprys goed beplan word en 'n regte-uitgifte gedurende 'n stygende konjunktuurfase onderneem word.

Die invloed van 'n regte-uitgifte op die markpryse van die bestaande aandele is van groot belang, want die verskil tussen die markprys en die uitgifteprys maak 'n regteuitgifte tog aantreklik vir beleggers. 'n Model wat die markpryse en die sektorale indekse van die Rand Daily Mail in ag geneem het, toon die volgende afleidings: ${ }^{2}$

- Die aankondiging van 'n regte-uitgifte kan 'n positiewe of negatiewe invloed op die markprys van die bestaande aandele hê, in teenstelling met die teoretiese verwagting dat die markprys van die bestaande aandele by die aankondiging van 'n regte-uitgifte gaan styg.

- Die volgende formule is welbekend in akademiese handboeke:

$$
\mathbf{v}=\frac{\mathbf{M}-\mathbf{S}}{\mathbf{N}+\mathbf{T}}
$$

waar: $\mathbf{V}=$ die teoretiese waarde van een voorkeurreg

$\mathbf{M}=$ die markprys per aandeel van die bestaande aandele in die cum regte periode, dit is vanaf die amptelike aankondiging van die regte-uitgifte tot die laaste datum vir registrasie as andeelhouer van die maatskappy

$\mathbf{S}=$ die uitgifteprys per aandeel van die addisionele aandele

$\mathbf{N}=$ die aantal voorkeurregte wat nodig is om een nuwe aandeel op te neem.

Indien die markpryse van die aandele saam met die sektorale indekse beweeg, is die bogenoemde formule se praktiese waarde twyfelagtig.

- Die mate waartoe die veranderinge in die markpryse van bestaande aandele gedurende die ex regte periode (naamlik vanaf die laaste datum vir registrasie as aandeelhouer van die maatskappy tot die sluitingsdatum van die regte-uitgifte) gereflekteer word in die markpryse van die toekenningsbriewe is onvoorspelbaar. Dit wil voorkom asof die invloed van addisionele faktore tot 'n groter mate gereflekteer word in die markpryse van die toekenningsbriewe gedurende die dalende fases van die konjunktuur as in die stygende fases. 


\section{Kapitalisasie-uitgiftes}

In teenstelling met ' $n$ regte-uitgifte word addisionele aandele by ' $n$ kapitalisasie-uitgifte aan bestaande aandeelhouers gegee deur die reserwes te verminder. Verdeelbare reserwes ${ }^{3}$ sowel as statutêre nie-verdeelbare reserwes ${ }^{4}$ (die kapitaalaflossingsreserwefonds en die aandelepremie) mag gebruik word vir 'n kapitalisasie-uitgifte. Gerealiseerde kapitaalwins wat voortspruit uit 'n voorinlywingskontrak en die verkoop van vaste bates mag ook hiervoor aangewend word. ${ }^{3 \text { pp }} 310+307$

'n Kapitalisasie-uitgifte word. weens die volgende redes onderneem: Eerstens word verdeelbare reserwes omskep in permanente kapitaal wat 'n duursame kapitaalbehoefte bevredig. Sodoende word verdeelbare reserwes wat verminder kan word deur dividenduitkering omgeskep in aandelekapitaal wat nie sonder meer verminder kan word nie. Voorts kan die bemarkbaarheid van die aandele verhoog word omdat die aantal uitgereikte aandele vermeerder en volgens die wet van aanbod en vraag verwag word dat die markprys sal verminder om sodoende binne die bereik van die klein beleggers te kom. Derdens behoort die druk op die maatskappy om die verdeelbare reserwes uit te keer as gevolg van 'n kapitalisasie-uitgifte af te neem.

Wat die uitgifteverhouding betref word 'n groot verskeidenheid in die praktyk aangetref, aangesien dit beinvloed word deur die pariwaarde per aandeel en die reserwes beskikbaar vir die omskepping in aandelekapitaal. Volgens die betrokke maatskappye het die kapitalisasieuitgiftes wel voordele vir die aandeelhouers ingehou. Behalwe die verhoging van die aandele se bemarkbaarheid en die meegaande wyer verspreiding van die aandele tussen beleggers gee ' $n$ kapitalisasie-uitgifte aan beleggers die moontlikheid om die kapitalisasie-aandele te verkoop. Soos algemeen bekend, is die kapitaalwins wat gemaak word by die verkoop van aandele gewoonlik belastingvry. Dit is ten slotte duidelik dat maatskappye die belange van die aandeelhouers in ag neem by ' $n$ kapitalisasie-uitgifte.

\section{Die verband fussen regte-uitgifte en kapltalisasie- uitgifte}

Die verband tussen regte-uitgifte en kapitalisasie-uitgifte kan met behulp van die volgende voorbeeld geillustreer word': Gestel 'n bepaalde maatskappy se markprys per aandeel voor 'n regte-uitgifte is gelyk aan R52 en die uitgifteprys per addisionele aandeel beloop R40. Neem verder aan dat die uitgifteverhouding gelyk aan een addisionele aandeel vir elke vyf bestaande aandele is. Die teoretiese waarde van een voorkeurreg volgens die formule genoem in die afdeling oor regte-uitgiftes beloop dan R2. Indien ' $n$ aandeelhouer 100 bestaande aandele besit, kry hy voorkeurregte ter waarde van R200. Neem verder aan dat hy 80 voorkeurregte verkoop en daarvoor R160 ontvang. Die oorblywende 20 voorkeurregte kan hy nou uitoefen en vier nuwe aandele koop wat ook R 160 bedra. Die betrokke aandeelhouer kry gevolglik vier addisionele aandele sonder dat hy self kontant in die proses hoef by te dra.

Die resultaat is dieselfde as waar vier kapitalisasieaandele vir 100 bestaande aandele uitgereik word. ' $\mathrm{B}$ Belangrike verskil is egter dat die aandeelhouer by ' $n$ kapitalisasie-uitgifte sy relatiewe aandeelhouersbelang in die maatskappy sou handhaaf terwyl dit nie die geval by 'n regte-uitgifte sou gewees het nie.

\section{Onderverdelings van aandele}

'n Onderverdeling van aandele behels die pro rata vermindering van die pariwaarde per aandeel met 'n oorstemmende vermeerdering in die aantal uitgereikte aandele sodat die uitgereikte aandelekapitaal konstant bly. Daar is gevolglik geen sprake van kontantvloeiing nie.

Die belangrikste rede waarom 'n onderverdeling van aandele plaasvind, is ' $n$ poging om die bemarkbaarheid van die aandele te verhoog. Volgens $93 \%$ van die meewerkende ondernemings kan die verhandelbaarheid van die aandele verhoog word aangesien die aantal uitgereikte aandele toeneem terwyl die pariwaarde per aandeel pro rata daal tesame met ' $n$ verwagte daling in die markprys per aandeel. Sodoende behoort die markprys binne die bereik van die klein belegger te kom, met die meegaande wyer verspreiding van die aandele tussen beleggers. Dit sal derhalwe lei tot ' $n$ meer realistiese markprys en beleggers se beleggingsportefeuljes kan moontlik 'n groter diversiteit geniet.

Die onderverdelingsverhouding het slegs vier moontlikhede getoon. Een bestaande aandeel is onderverdeel in twee, vier, vyf of 10 aandele. Hierdie vier onderverdelingsverhoudings was ongeveer ewe gewild in die praktyk. 'n Logiese rede vir hierdie vier onderverdelingsverhoudings is dat die pariwaarde per aandeel meestal 'n ewe getal is en dat die onderneming poog om die pariwaarde per aandeel 'n ewe getal te hou.

Slegs twee van die 27 meewerkende ondernemings het aangedui dat die onderverdeling van aandele geen voordeel vir die aandeelhouers ingehou het nie. Die oorblywende 25 maatskappye het dieselfde voordele aangedui wat hier bo as die redes vir onderverdelings van aandele bespreek is.

Ten slotte is dit nodig om op te merk dat 'n onderverdeling van aandele ook die balansstaatwaarde per aandeel, wins per aandeel en dividend per aandeel pro rata beïnvloed. So ' $n$ verandering in aandelekapitaal sal egter geen invloed op die winsvermoë of die likiditeit van die onderneming hê nie.

Gelyktydige verminderinge van aandelekapitaal en konsolidasies van aandele, asook verminderinge van aandelekapitaal

Hierdie afdeling behels in alle gevalle die vermindering van aandelekapitaal en in sommige gevalle word die vermindering van aandelekapitaal opgevolg met 'n konsolidasie van aandele.

Die vermindering van aandelekapitaal beteken dat die uitgereikte aandelekapitaal verminder word. Gewoonlik bly die aantal uitgereikte aandele konstant terwyl die pariwaarde per aandeel verminder. By die inkorporasie van 'n maatskappy is die totale kapitaal onderhewig aan heelwat risiko en die klem val sterk op die eie kapitaal wat dien as ' $n$ dekking vir die vreemde kapitaal. Indien die maatskappy se finansiële posisie verbeter, verskuif die klem al hoe meer na die aantrekking van vreemde kapitaal aangesien die finansiële hefboom voordele mag inhou. In hierdie stadium mag die maatskappy die vermindering van sy aandelekapitaal oorweeg. ${ }^{6}$

'n Maatskappy mag normaalweg nie sy eie aandele koop en dit as ' $n$ belegging in die balansstaat toon 
nie. 3. p 292 Volgens die Maatskappyewet van 1973 bestaan daar slegs twee wyses waarvolgens 'n maatskappy sy aandelekapitaal mag verminder, naamlik:

- 'n Maatskappy mag opgehoopte verliese teen die aandelekapitaal afskryf,

- 'n Maatskappy mag 'n gedeelte van sy aandelekapitaal terugbetaal aan die betrokke aandeelhouers.

Ses van die nege meewerkende ondernemings het 'n gedeelte van die aandelekapitaal terugbetaal aan die betrokke aandeelhouers, terwyl die oorblywende maatskappye opgehoopte verliese teen hulle aandelekapitaal afgeskryf het. Verder blyk dit uit die navorsing dat vyf maatskappye oortollige fondse terugbetaal het, terwyl een maatskappy meer onafhanklik van eksterne kapitaalbronne wou wees.

Die finansiële oorwegings by ' $n$ vermindering van aandelekapitaal is belangrik. Die ondernemingsrentabiliteit mag styg indien oortollige fondse, waarvan die opbrengs laag mag wees, terugbetaal word. In hierdie geval sal die solvabiliteitsverhouding daal en kontantuitvloeiing tot gevolg hê. Indien die aandelekapitaal egter verminder word deur opgehoopte verliese daarteen af te skryf, word die ondernemingsrentabiliteit, solvabiliteitsverhouding en likiditeitsposisie nie beinvloed nie.

Nadat ' $n$ vermindering van aandelekapitaal plaasgevind het, was party van die maatskappye van mening dat 'n konsolidasie van aandele nodig was. Hieronder word die vermeerdering van die pariwaarde per gewone aandeel met 'n pro rata vermindering in die aantal uitgereikte aandele verstaan sodat die uitgereikte aandelekapitaal konstant bly. Sodoende sal die balansstaatwaarde per aandeel pro rata styg en die verwagting bestaan dat die markprys per gewone aandeel op 'n hoër vlak te staan sal kom. By 'n konsolidasie van aandele word geen invloed op die ondernemingsrentabiliteit, solvabiliteitsverhouding of die likiditeitsposisie bespeur nie. Die wins per aandeel sal egter pro rata styg.

\section{Samevatting en aanbevelings}

'n Deeglike ontleding van historiese gegewens is nodig voordat ' $n$ verandering in die aandelekapitaal onderneem word. Hierdie ontleding behoort nie net finansiële resultate in te sluit nie, maar ook die beleggingsoorwegings van die betrokke aandeelhouers wat kapitaalgroei of inkomsteverkryging mag verlang. Byvoorbeeld, by die bepaling van die uitgifteprys van ' $n$ regte-uitgifte behoort die tendens van die markpryse van die aandele hoë prioriteit te geniet.

Weldeurdagte beplanning behoort ook hierdie veranderinge in aandelekapitaal vooraf te gaan, want 'n maatskappy sal vir ' $n$ lang periode hieraan gebonde wees. So sal gelet moet word op die invloed wat 'n verandering in die aandelekapitaal op die balansstaatwaarde per aandeel, wins per aandeel asook die markprys van die aandele sal hê.

\section{Summary}

This article takes the following changes in share capital into consideration, namely rights issues, capitalization issues, subdivisions of shares, reductions of share capital and consolidations of shares during the periode 1965 to 1974 .
The discussion of rights issues conclude that it was undertaken to finance expansion investments rather than replacement investments. It seems as though the companies were capable to do replacement investments through internal funds, but that expansion investments were a problem. The profitability of the additional share capital was a critical factor for the existing shareholders, as 65 per cent of the companies mentioned the expected dividend rate in their invitation to subscribe to the additional shares.

The discount rate in terms of the existing market prices was in 81 per cent of the cases equal to, or less than 35 per cent. No significant correlation could be found between the discount rates and the upward and downward phases of the business cy. cle. Almost 76 per cent of the examined rights issues were successful as 90 per cent or more of the additional shares were taken up. The hypothesis that rights issues have a better chance to be successful during the upward phase of the business cycle, was empirically proved. The underwriting of rights issues is almost a standard procedure in South $\mathrm{Africa}$, as only four of the 80 companies did not use it.

The capitalization issues were undertaken for the following reasons: Distributable reserves were converted into permanent capital, the marketability of the shares was increased, and the pressure on the company to distribute reserves in the form of dividends was eliminated. A variety of issue ratios were found, as a capitalization issue is being influenced by the par value of the shares and the amount of the available reserves.

The subdivisions of shares were an attempt to improve the marketability of the shares by increasing the number of issued shares and decreasing the market price per share. Only two of the 27 companies indicated that the subdivisions of shares were not beneficial to the existing shareholders. One existing share was divided into two, four, five or ten shares in order to keep the par value an even number.

A reduction of share capital means that the issued share capital has been reduced. This can be done by reducing the number of shares while the par value remains the same, or by keeping the number of shares as before and reducing the par value per share. Most companies chose the last alternative. It is possible to reduce the existing share capital by repaying a part of the share capital or by decreasing the share capital equal to the amount of accumulated losses. The majority chose the first alternative to reduce their share capital as they had surplus funds. The financial considerations include the profitability of the company, the solvency ratio and the cash flow that may result from a reduction of share capital.

To increase the par value per share to a more realistic level after a reduction of share capital occurred, a consolidation of shares was necessary according to a few companies. The issued share capital remains the same as before, while the number of shares decreases.

\section{Verwysings}

1. MOSTERT, F.J. 'n Empiriese studie van sekere veranderinge in die gewone aandelekapitaal van genoteerde maatskappye in SuidAfrika, 1965 tot 1974, Ongepubliseerde M.Comm.-skripsie, Universiteit van Stellenbosch, Stellenbosch 1976. Die Navorsingsfonds van die Universiteit van Stellenbosch het finansiële bystand verleen.

2. LAMBRECHTS, I.J., \& MOSTERT, F.J. An analysis of the behaviour of market prices during rights issues. Invest. Anal. J. 15, Mei 1980.

3. CILllERS, H.S., \& BENADE, M.L. Maatskappyereg, Butterworths, Durban, Derde uitgawe, 1977, p. 312.

4. Maatskappywet no. 61 van 1973, soos gewysig, artikels 98(4), 76(3) en $84(1)$.

5. BLOCK, F.E. Per share adjustments for rights, Fin. Anal. J. 21, Mei 1965, p. 58.

6. ZWENDLING, G.H. Stock Repurchase: Financial Issues, Calif. Mgmi Rev. 11, Winter 1968, p. 30. 